\title{
Rancang Bangun Sistem Informasi Geografis Potensi Sumber Daya Alam Di Kabupaten Talaud Berbasis Web
}

\author{
Arief A. Sasoeng ${ }^{1)}$, Steven R. Sentinuwo ${ }^{2)}$, Yaulie Deo Y. Rindengan ${ }^{3)}$ \\ Program Studi Teknik Informatika, Fakultas Teknik, Universitas Sam Ratulangi \\ 13021106186@student.unsrat.ac.id, Steven@unsrat.ac.id, rindengan@gmail.com
}

\begin{abstract}
Sistem Informasi Geografis (SIG) atau Geographic Information System (GIS) adalah sebuah sistem yang didesain untuk menangkap, menyimpan, memanipulasi, menganalisa, mengatur dan menampilkan seluruh jenis data geografis, misalnya informasi-informasi yang berkaitan dengan sumber daya alam, maka informasi geografis akan berisi mengenai lokasi suatu daerah dan informasi mengenai sumber daya alam yang terkandung pada daerah tersebut. Kabupaten Kepulauan Talaud merupakan salah satu daerah terpencil yang berada di Provinsi Sulawesi Utara, Indonesia yang berbatasan dengan daerah Davao del Sur, Filipina disebelah utara, Ibu Kota Melonguane. Dengan merancang dan membagun sistem informasi geografis mengenai potensi sumber daya alam di Kabupaten Kepulauan Talaud berbasis web, dapat memberikan informasi data-data potensi sumber daya alam di Kabupaten Kepulauan Talaud. Dengan menggunakan metode Waterfall dalam membuat suatu sistem informasi menggunakan bahasa pemprograman PHP, HTML dan MYSQL.
\end{abstract}

Kata kunci - GIS, Potensi, SDA, SIG, Talaud, Web.

Abstract - System Information Geographic (SIG) or Geographic Information System (GIS) is a system designed to capture, store, manipulate, analyze, organize and display all types of geographic data, such as information relating to natural resources, geographical information will contain the location of an area and information about the natural resources it contained in the area. Talaud islands Districts is one of the remote areas located in North Sulawesi Province, Indonesia bordering the Davao del Sur, Philippines region to the north, of capital Melonguane. By designing and Building geographic information system on the potential of natural resources in the web based talaud island district, can provide information of potential natural resource data in Talaud Islands District. By using Waterfall method in making an information system using programming language $\mathrm{PHP}, \mathrm{HTML}$ and MYSQL.

Keywords - GIS, Potency, SDA, SIG, Talaud, Web.

\section{Pendahuluan}

Sistem Informasi Geografis (Geographic Information System) adalah sistem informasi yang mengelola data yang memiliki informasi spesial atau dalam arti yang lebih sempit adalah sistem komputer yang memiliki kemampuan untuk membangun, menyimpan, mengelola dan menampilkan informasi berefrensi geografis[11].

Misalnya informasi-informasi yang berkaitan dengan sumber daya alam. Informasi geografis akan berisi mengenai lokasi suatu daerah dan informasi mengenai sumber daya alam yang terkandung pada daerah tersebut.

Kabupaten Kepulauan Talaud yang merupakan salah satu daerah terpencil yang berada di Provinsi Sulawesi Utara, Indonesia yang berbatasan dengan daerah Davao del Sur, Filipina di sebelah utara. Dengan ibu kota Melonguane. Kabupaten Kepulauan Talaud memiliki Potensi Sumber Daya Alam yang terdiri dari Sektor Primer, antara lain Pertanian, Perkebunan, Perternakan, Perikanan dan Kehutanan.

Permasalahan yang ada di Kabupaten Kepulauan Talaud adalah kurangnya informasi potensi sumber daya alam kepada masyarakat sehingga masyarakat sulit untuk mengetahui informasi potensi sumber daya alam yang ada di Kabupaten Kepulauan Talaud.

Dengan adanya sistem informasi geografis ini dapat mempercepat dan mempermudah informasi potensi sumber daya alam yang ada di Kabupaten Kepulauan Talaud kepada masyarakat, sehingga masyarakat mendapatkan data yang telah diolah menjadi informasi sehingga dapat membantu masyarakat ataupun para pengusaha dari luar daerah untuk membuka usaha di Kabupaten Kepulauan Talaud.

Berdasarkan uraian diatas, maka penulis mengambil judul "Rancang Bangun Sistem Informasi Geografis Potensi Sumber Daya Alam di Kabupaten Talaud Berbasis Web "sebagai tugas akhir. Sehingga diharapkan dengan dibuatnya sistem informasi ini dapat memberikan suatu informasi mengenai potensi sumber daya alam di Kabupaten Kepulauan Talaud secara optimal.

\section{1) Kabupaten Kepulauan Talaud}

Kabupaten Kepulauan Talaud adalah salah satu Kabupaten di Provinsi Sulawesi Utara, Indonesia dengan ibu Kota Melonguane. Kabupaten ini berasal dari pemekaran dari Kabupaten Kepulauan Sangihe (pada saat itu masih Kabupaten Kepulauan Sangihe Talaud), berdasarkan Undang-Undang No. 8 Tahun 2002[3]. Kepulauan Talaud merupakan bagian integral dari Propinsi Sulawesi Utara yang berjarak sekitar 271 mil laut dari Manado Ibukota Provinsi Sulawesi Utara, terletak 


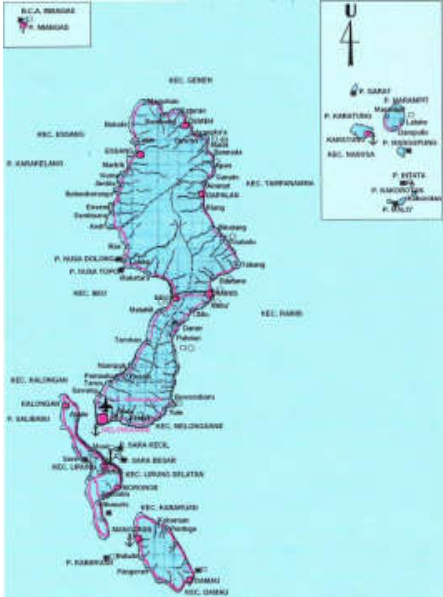

Gambar 1. Tampilan Peta Wilayah Kabupaten Kepulauan Talaud

pada posisi geografis $3^{\circ} 38^{\text {ee }} 00^{\circ}$ "- $5^{\circ} 33^{\text {ee }} 00^{\prime}$ Lintang Utara dan $126^{\circ} 38^{\text {ee }} 00^{\prime \prime}-127^{\circ} 10^{\text {ee }} 00^{\prime \prime}$ Bujur Timur, di mana batas administrasi Kabupaten Kepulauan Talaud adalah sebagai berikut[3]:

a. Sebelah Utara berbatasan dengan Republik Filipina (P. Mindanau)

b. Sebelah Timur berbatasan dengan Laut Pasifik

c. Sebelah Selatan berbatasan dengan Kabupaten Kepulauan Sangihe

d. Dan Sebelah Barat berbatasan dengan Laut Sulawesi. Adapun dapat lihat tampilan peta wilayah Kabupaten Kepulauan Talaud pada gambar 1 .

\section{2) Pengertian Sistem}

Sistem merupakan sekumpulan komponen yang saling berelasi untuk mencapai tujuan dengan menerima masukan dan menghasilkan keluaran melalui proses transformasi yang terorganisasi[8].

\section{3) Pengertian Informasi}

Informasi adalah data yang sudah diolah sehingga data tersebut bias dijadikan sandaran dalam mengambil keputusan yang tepat. Data yang sudah diproses sedemikian rupa yang dapat meningkatkan pengetahuan seorang yang menggunakannya[8].

\section{4) Pengertian Sistem Informasi}

Sistem informasi dapat diartikan sebagai sekumpulan komponen yang saling berhubungan dalam mengumpulkan atau menerima, proses, menyimpan, dan mendistribusikan informasi untuk mendukung pengambilan keputusan, koordinasi dan pengaturan dalam sebuah organisasi[8].

\section{5) Pengertian Geografis}

Menurut Ramaini (1992) [8] Geografis adalah ilmu pengetahuan yang mempelajari tentang permukaan bumi, penduduk dan hubungan timbal balik antara keduanya. Permukaan bumi dalam pengertian diatas dapat diartikan sebagai daratan, air atau perairan, dan lapisan-lapisan udara.
Juga dapat didefinisikan sebagai tempat berlangsungnya kehidupan mahluk hidup.

\section{6) Sistem Informasi Geografis}

Sistem Informasi Geografis (SIG) atau Geographic Information System (GIS) adalah sebuah sistem yang didesain untuk menangkap, menyimpan, memanipulasi, menganalisa, mengatur dan menampilkan seluruh jenis data geografis[4].

Definisi dari sistem informasi geografis adalah sebuah sistem informasi dari hardware yang mendukung untuk menyusun, mengelola, menganalisi, dan menvisualisasikan data geografis[4].

Komponen-komponen pendukung SIG terdiri dari lima komponen yang bekerja secara terintegrasi yaitu perangkat keras (hardware), perangkat lunak (software), data, manusia, dan metode[1].

Menurut Prahasta (2002) [5] Manfaat SIG adalah meningkatkan kemampuan menganalisis informasi spasial secara terpadu untuk perencanaan dan pengambilan keputusan. SIG dapat memberikan informasi kepada pengambil keputusan untuk analisis dan penerapan database keruangan.

Untuk membuat suatu perencanaan pembangunan atau pengambilan keputusan yang berkaitan dengan spasial diperlukan analisis data yang bereferensi geografis. Analisis ini harus didukung oleh sejumlah konsep-konsep ilmiah dan sejumlah data yang handal. Data atau informasi yang berkaitan dengan permasalahan akan dipecahkan harus dipilih dan diolah melalui pemrosesan yang akurat. Untuk keperluan tersebut SIG menyediakan sejumlah subsistem data input, data output, data management, dan data manipulation dan analysis [4].

Menurut Prahasta Eddy (2005) [5] Sistem Informasi Geografis dapat menyajikan real world (dunia nyata) pada monitor sebagaimana lembaran peta dapat merepresentasikan dunia nyata diatas kertas. Tetapi, SIG memiliki kekuatan lebih dan fleksibilitas dari pada lembaran pada kertas. Peta merupakan representasi grafis dari dunia nyata, obyek-obyek yang dipresentasikan di atas peta disebut unsur peta atau map features contohnya adalah sungai, taman, kebun, jalan dan lain-lain.

\section{7) Perangkat Lunak ArcGIS}

ArcGis adalah sebuah solusi software (perangkat lunak) aplikasi Sistem Informasi Geografis (SIG) yang integral. Di dalam ArcGis terdapat beberapa aplikasi Sistem Informasi Geografis yang memiliki fungsi berbeda-beda. Di antaranya adalah ArcView, ArcMap, ArcCatalog dan ArcReader. ArcGis ini dikembangkan oleh ESRI (Environmental System Research Institude). Sebuah perusahaan yang memfokuskan diri pada solusi pemetaan digital terintegrasi. ArcGis adalah salah satu dari sekian banyak produk yang saling terkait di bidang pemetaan digital yang dikembangkan oleh ESRI[10].

Quantum GIS (QGIS) adalah cross-platform perangkat lunak bebas (open source) desktop pada sistem informasi geografis (SIG). aplikasi ini dapat menyediakan data, melihat, mengedit, dan kemampuan analisis. Quantum GIS berjalan pada sistem operasi yang berbeda termaksuk Mac OS X, Linux, UNIX, dan Microsoft Windows. Dalam perizinan, QGIS sebagai perangkat lunak bebas aplikasi di bawah 
GPL(General Public License), dapat secara bebas dimodifikasi untuk melakukan tugas yang berbeda atau lebih khusus[1].

\section{8) Aplikasi Web}

Aplikasi web merupakan sebuah aplikasi yang mengunakan teknologi browser untuk menjalankan aplikasi dan diakses melalui jaringan komputer. Aplikasi web juga merupakan suatu perangkat lunak komputer yang dikodekan dalam bahasa pemrograman yang mendukung perangkat lunak berbasis web seperti HTML, JavaScript, CSS, Ruby, Python, Php, Java dan bahasa pemrograman lainnya[2].

PHP adalah Bahasa pelengkap HTML yang memungkinkan dibuatnya aplikasi dinamis yang memungkinkan adanya pengolahan data dan pemrosesan data[9].

MySQLi adalah database relasional yang digunakan dalam bahasa pemrograman PHP, untuk menyediakan sebuah antarmuka dengan MySQL database[12].

Bootstrap adalah kerangka kerja terpopuler untuk membangun proyek mobile pertama yang responsive diweb dengan komponen perpustakaan front-end. Bootstrap adalah tollkit open source untuk pengembangan dengan HTML, CSS dan JS[9].

\section{9) Model Air Terjun (Waterfall)}

Model air terjun (waterfall) juga dinamakan siklus hidup klasik (classic life cycle), dimana hal ini menyiratkan pendekatan yang sistematis dan berurutan (sekuensial) pada pengembangan perangkat lunak, yang dimulai dengan spesifikasi kebutuhan pengguna dan berlanjut melalui tahapan perencanaan (planning), pemodelan (modeling), konstrusi (construction), serta penyerahan sistem perangkat lunak ke para pelanggan atau pengguna (deployment), adapun diakhiri dengan dukungan berkelanjutan pada perangkat lunak. Dapat dilihat proses alur kerja model air terjun (waterfall) pada gambar 2[7].

\section{0) Хатрp}

XAMPP adalah perangkat lunak bebas, yang mendukung banyak system operasi, merupakan kompilasi dari beberapa program. Fungsinya adalah sebagai server yang berdiri sendiri (localhost), yang terdiri atas program Apache HTTP Server, MySQL database, dan penerjemah bahasa yang ditulis dengan bahasa pemrograman PHP dan Perl [5].

\section{1) Google Maps API}

Google Maps API adalah suatu library yang berbentuk JavaScript. Cara membuat Google Maps untuk ditampilkan pada suatu web atau blog sangat mudah hanya dengan membutuhkan pengetahuan mengenai HTML serta JavaScript, serta koneksi Internet yang sangat stabil[6].

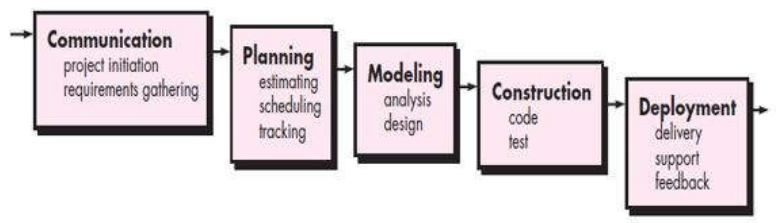

Gambar 2. Model Air Terjun (Waterfall)

\section{II.METODOLOGI PENELITIAN}

\section{1) Kerangka Pikir}

Kerangka Piker merupakan bagian yang menguraikan tahapan proses alur kerja atau alur penelitian yang dapat dilihat pada gambar 3 .

\section{2) Metode Pengembangan Sistem}

Pada pengembangan sistem ini penulis menggunakan metode waterfall untuk membangun sistem yang memberikan sebuah pendekatan yang dimulai pada komunikasi, perencanaan, pemodelan, konstruksi dan penyerahan sistem ke para pelanggan/pengguna. Berikut adalah contoh alur cara kerja Metode Pengembangan Sistem pada gambar 4.

\section{3) Perencanaan / Analisa Kebutuhan Sistem}

Tahap perencanaan atau analisa kebutuhan sistem adalah teknik-teknik untuk membangun suatu sistem dengan melakukan pengumpulan data, yaitu melakukan penelitian dan wawancara.

a. Prosedur penelitian

Langkah awal untuk mendapatkan suatu data yang lengkap dalam penelitian ini adalah dengan melakukan penelitian secara turun lapangan untuk mencari datadata potensi sumber daya alam di Kantor BAPELITBANG Kabupaten Kepulauan Talaud.

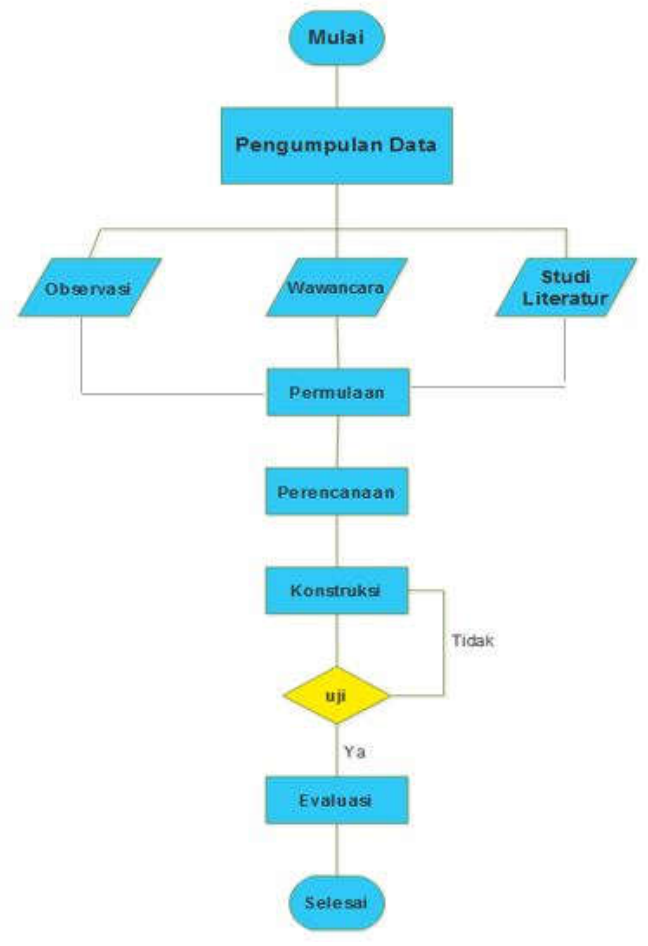

Gambar 3. Kerangka Pikir

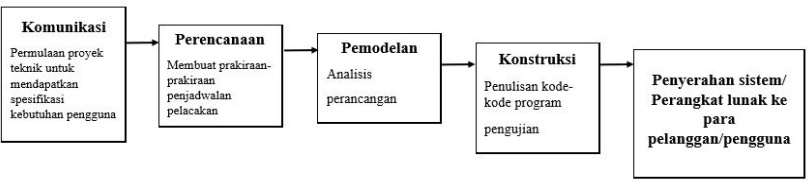

Gambar 4. Metode Pembuatan Sistem 
TABEL I

HASIL WAWANCARA

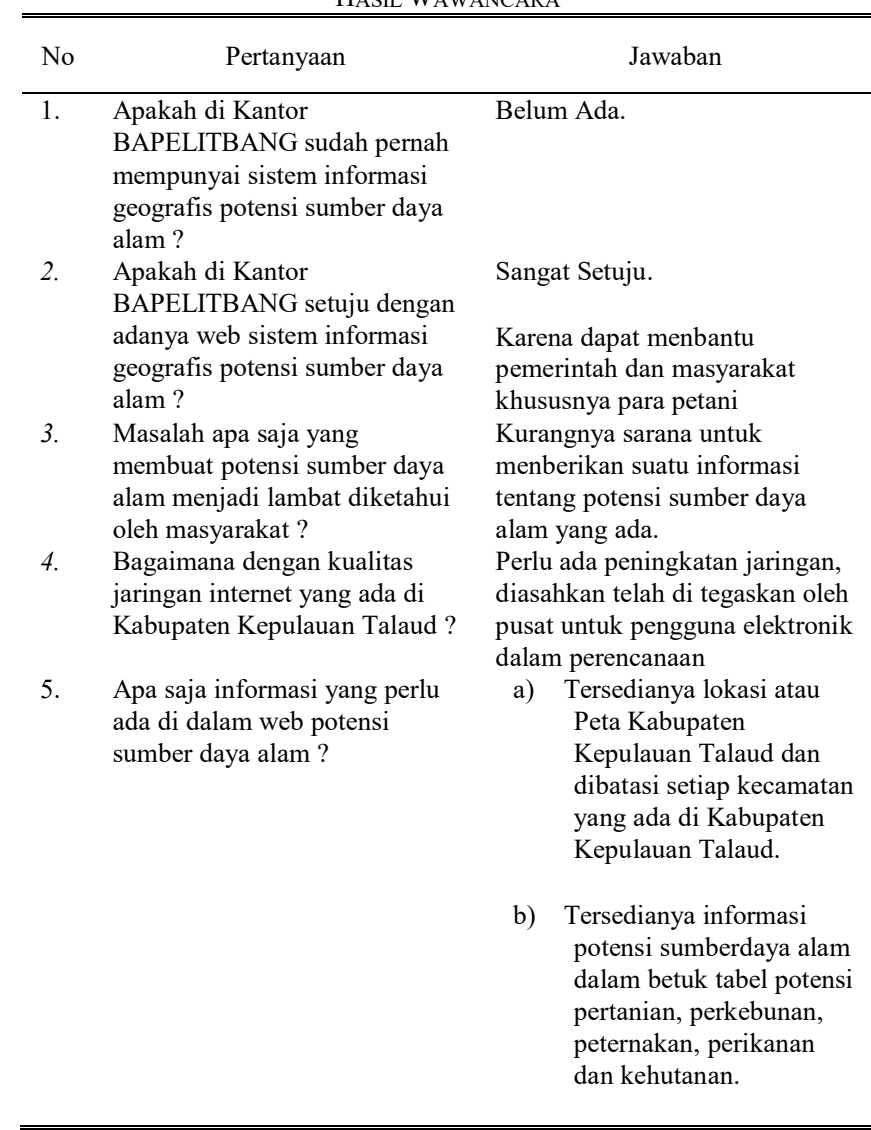

b. Prosedur wawancara

Berikut ini adalah hasil wawancara peneliti dengan Ibu Dr. Imelda Tingginehe, S.Pt. selaku kepala bidang penelitian dan pengembangan di Kantor BAPELITBANG di Kabupaten Kepulauan Talaud seperti berikut pada tabel 1 .

\section{4) Pemodelan Perangkat Lunak}

Perangkat lunak ini digunakan untuk kebutuhan identifikasi dan difokuskan pada sistem yang akan dibangun meliputi identifikasi informasi, tingkah laku sistem untuk kerja dan antar muka sistem. Kebutuhan untuk sistem didokumentasikan dan dikonsultasikan bagi pengguna. Oleh karena itu UML (Unified Modelling Languange) berfungsi sebagai alat bantu dalam pendekatan analisis berorientasi objek. Pada umumnya dalam bentuk use case dan diagram aktivitas.

a. Use Case Diagram

Use case Diagram adalah menggambarkan bagaimana sistem yang dirancang untuk menunjukan interaksi antara pengguna sistem dengan sistem itu sendiri yang terdiri use case description admin yang dapat di lihat pada gambar 5 dan juga use case description user yang dapat di lihat pada gambar 6 .

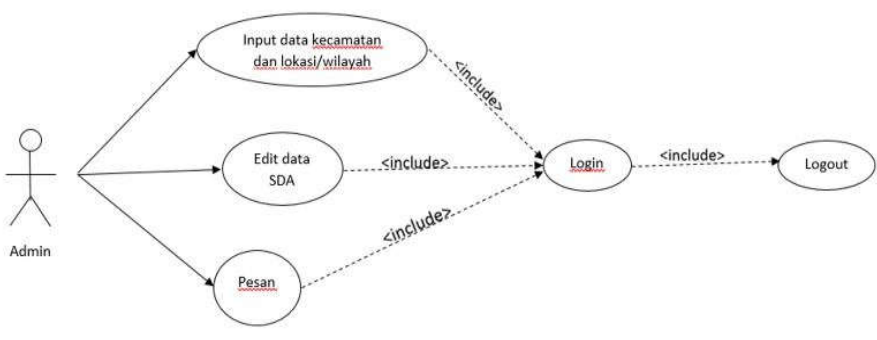

Gambar 5. Use case Diagram Admin

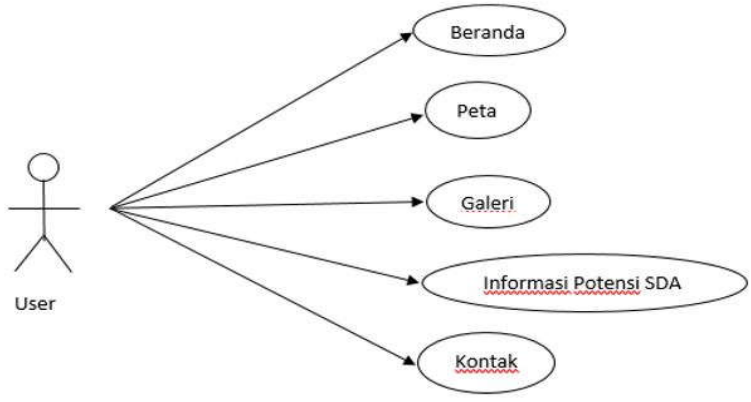

Gambar 6. Use Case Diagram User

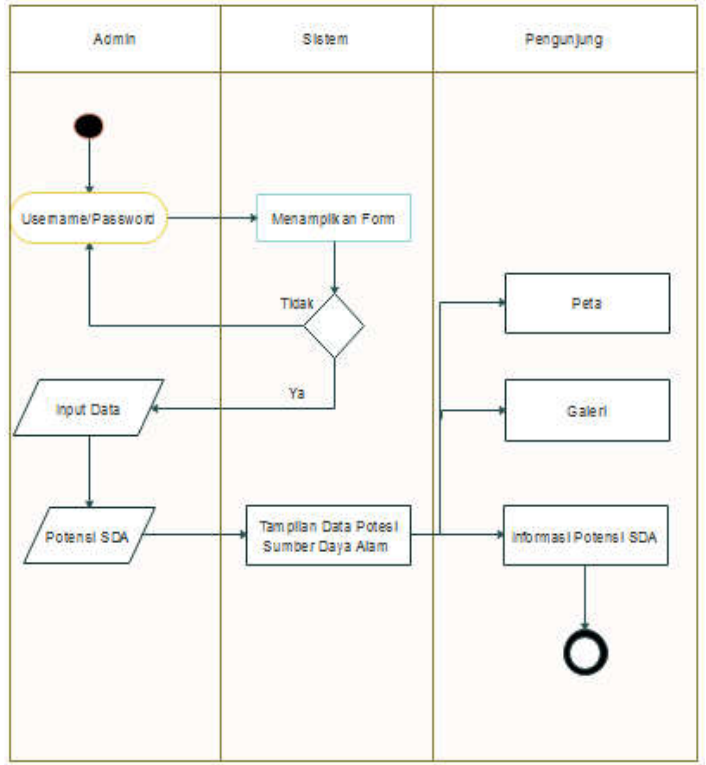

Gambar 7. Actifity Diagram

\section{b. Activity Diagram}

Activity Diagram ini menggambarkan proses atau aliran untuk menunjukan proses atau alur pada aplikasi web potensi sumber daya alam Kabupaten Kepulauan Talaud yang dapat di lihat pada gambar 7 .

\section{HASIL DAN PEMBAHASAN}

\section{1) Implementasi Perencangan Sistem}

Implementasi merupakan tahap menerjemahkan layout yang sudah dibuat pada desain perancangan antar muka kedalam bentuk tampilan implementasi sistem secara utuh. Setelah 
melakukan semua tahapan sesuai dengan metode pengembangan sistem yaitu Waterfall Model, pada tahap ini akan dijelaskan hasil dari penelitian yang dilakukan berdasarkan tujuan awal yaitu membuat suatu sistem.

a. Gambar 8 adalah tampilan menu beranda merupakan tampilan awal yang didalamnya berisi kata sambutan dari bupati talaud dan juga hasil jumlah potensi sumber daya alam.

b. Gambar 9 adalah tampilan menu peta yang dimana tampilannya menberikan informasi lokasi potensi sumber daya alam di setiap kecamatan yang ada di Kabupaten Kabupaten Talaud dan juga memiliki informasi-informasi.

c. Gambar 10 adalah tampilan menu galeri yang didalamnya terdapat informasi gambar potensi pertanian, perikanan, peternakan, perkebunan dan kehutanan di Kabupaten Kepulauan Talaud.

d. Gambar 11 adalah tampilan menu dropdown potensi pertanian yang dimana menyediakan informasi data potensi pertanian yang ada di Kabupaten Kepulauan Talaud, didalam menu dropdown potensi pertanian terdapat informasi berbentuk grafik.

e. Gambar 12 adalah tampilan menu dropdown potensi perkebunan yang dimana menyediakan informasi data potensi perkebunan yang ada di Kabupaten Kepulauan Talaud, dan juga menu dropdown potensi perkebunan terdapat informasi berbentuk grafik yang diambil dari datadata dalam tabel, seperti data kelapa, cengkih, pala dan abaca.

f. Gambar 13 adalah tampilan menu dropdown potensi peternakan yang dimana menyediakan informasi data potensi peternakan yang ada di Kabupaten Kepulauan Talaud, dan juga menu dropdown potensi peternakan terdapat informasi berbentuk grafik yang diambil data tahun, tersedia juga data populasi ternak, populasi unggas dan jumlah ternak yang di potong.
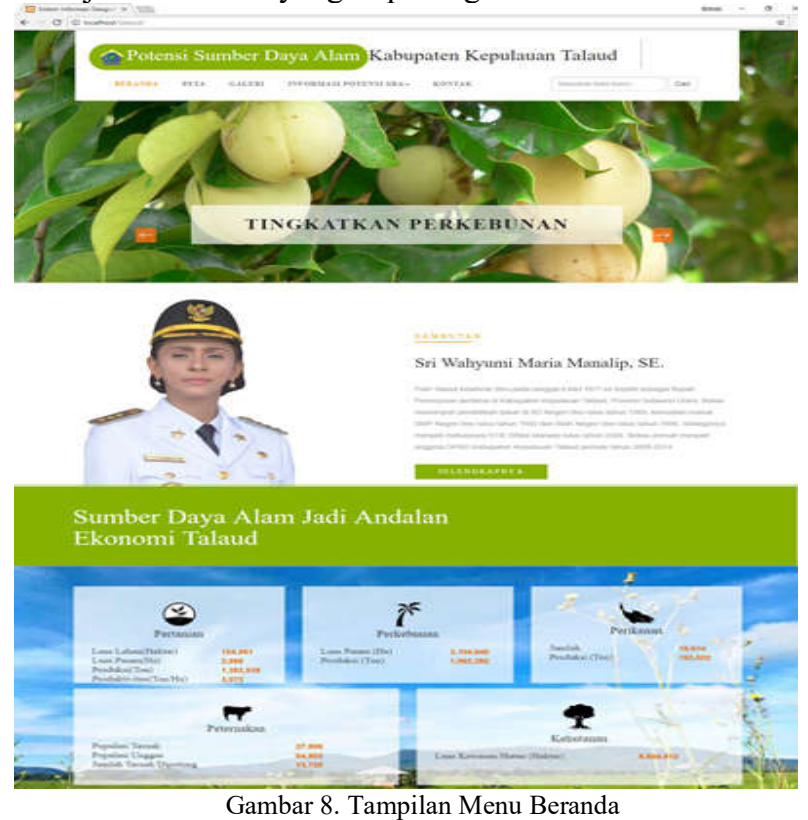

g. Gambar 14 adalah tampilan menu dropdown potensi perikanan yang dimana menyediakan informasi data potensi perikanan yang ada di Kabupaten Kepulauan Talaud. Didalam menu dropdown potensi perikanan terdapat informasi berbentuk grafik yang diambil data tahun, tersedia juga data jumlah produksi rumah tangga perikanan tangkap tahun 2015, jumlah produksi rumah tangga perikanan tangkap tahun 2016, jumlah rumah tangga perikanan budidaya, produksi perikanan budidaya dan jumlah perahu/kapal.

h. Gambar 15 adalah tampilan menu dropdown potensi kehutanan yang dimana menyediakan informasi data potensi kehutanan yang ada di Kabupaten Kepulauan Talaud. Didalam menu dropdown potensi kehutanan terdapat informasi berbentuk grafik yang diambil data tahun, tersedia juga data luas kawasan hutan dan perairan.

i. Gambar 16 merupakan tampilan login admin adalah halaman yang hanya bisa diolah oleh pihak yang mengelolah sistem informasi potensi sumber daya alam berbasis web.

j. Gambar 17 merupakan tampilan dashboard admin adalah tampilan halaman awal setelah tampilan login admin yang terdapat fungsih dan menu-menu yang nantinya digunakan untuk mengelolah aplikasi website tersebut.

k. Gambar 18 merupakan tampilan menu potensi SDA merupakan tampilan yang berisi menu dropdown pertanian, perkebunan, peternakan, perikanan dan kehutanan.

1. Gambar 19 merupakan tampilan menu dropdown pertanian merupakan tampilan menu dropdown bawang merah, buahbuahan, cabai, jagung, kacang hijau, kacang tanah, kedelai, ubi jalar, ubi kayu, padi ladang, padi sawah, sawah pengairan dan tegal lading.

m.Gambar 20 merupakan tampilan menu dropdown bawang merah adalah halaman untuk admin mengubah data luas panen(Ha) dan Produksi(Ton) yang berada pada data bawang merah. Begitu juga pada menu dropdown cabai, jagung, kacang hijau, kacang tanah, kedelai, ubi jalar, ubi kayu, padi ladang dan padi sawah.

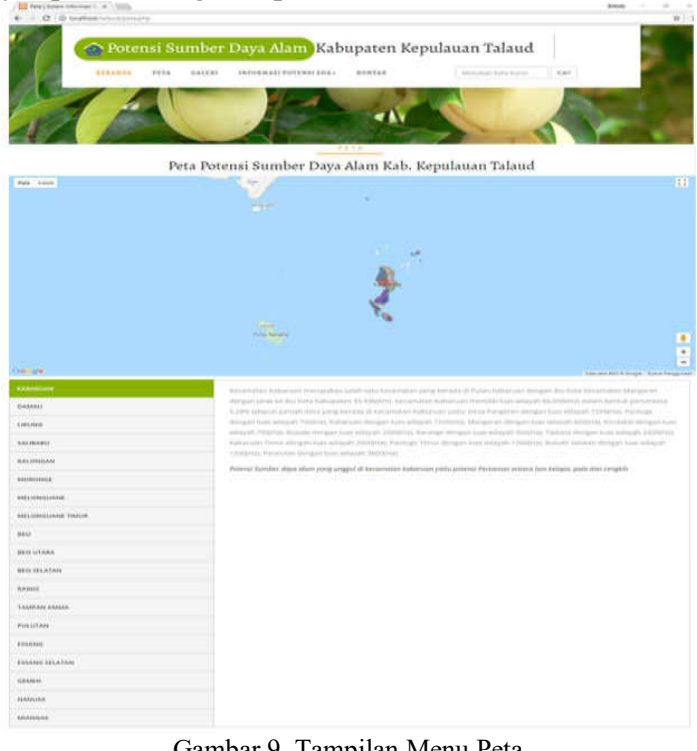

Gambar 9. Tampilan Menu Peta 


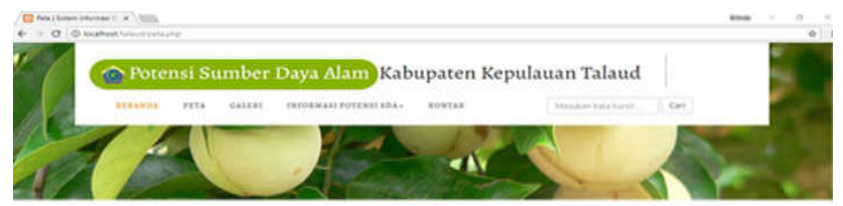

Galeri
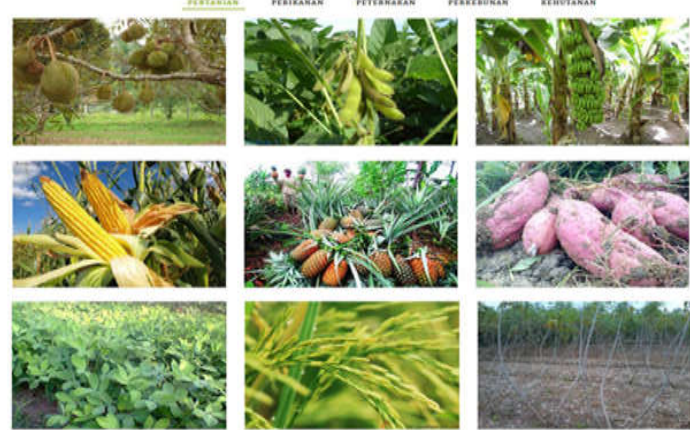

Gambar 10. Tampilan Menu Galer
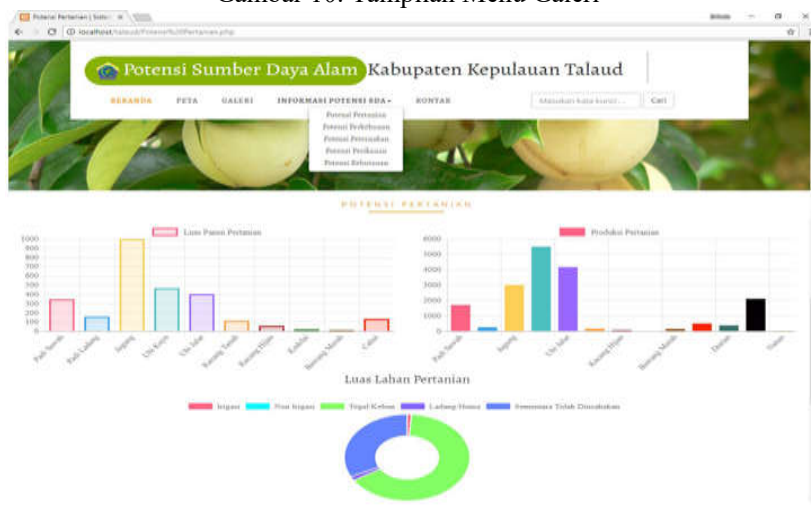

Luas Lithan
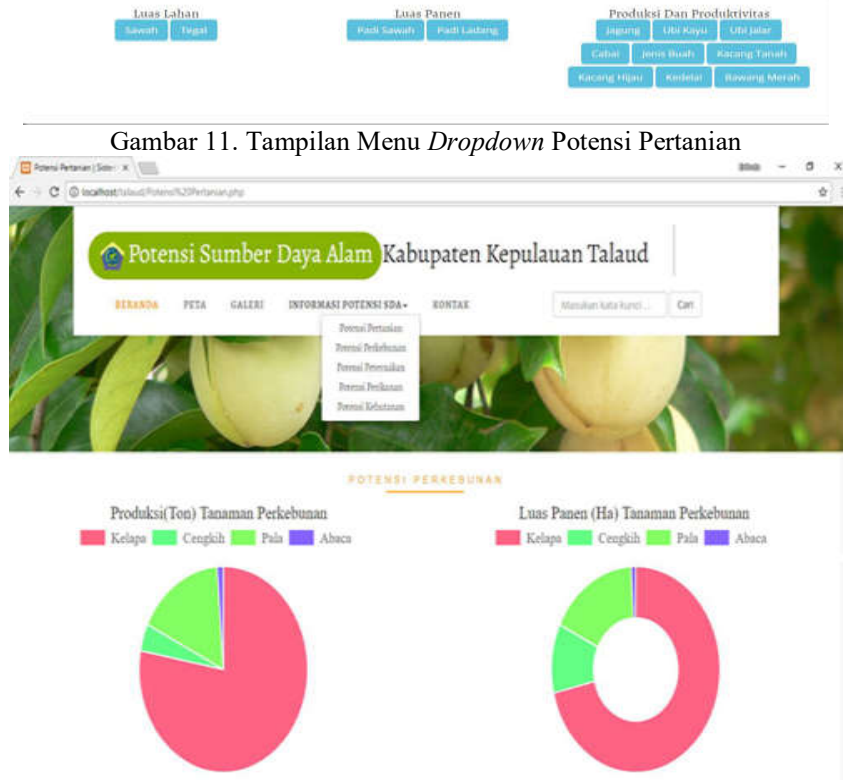

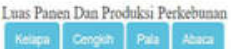

Gambar 12. Tampilan Menu Dropdown Potensi Perkebunan
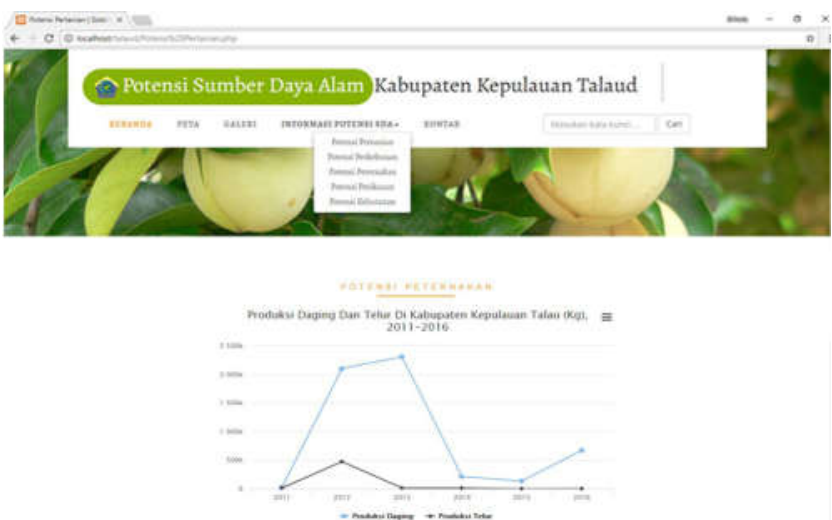

Populani Dan Juriatit Peternakaa
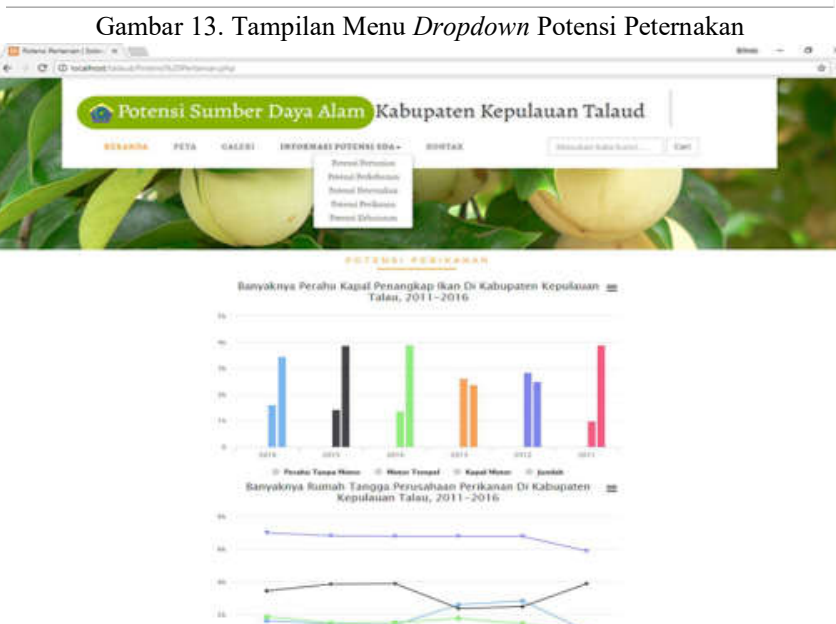

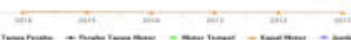
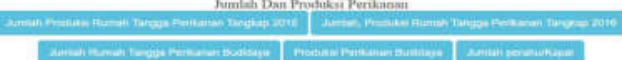

Gambar 14. Tampilan Menu Dropdown Potensi Perikanan

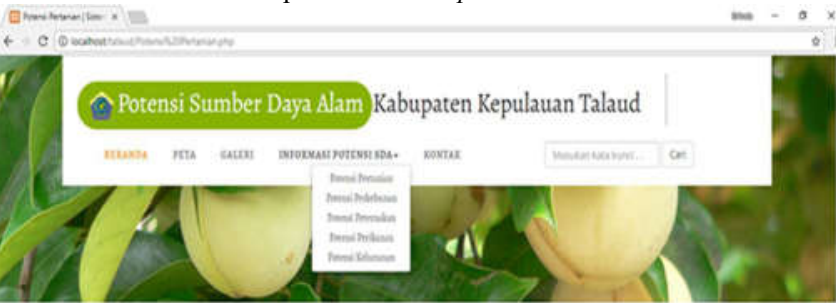

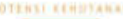

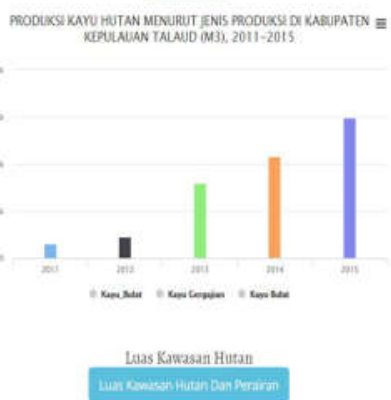

Gambar 15. Tampilan Menu Dropdown Potensi Kehutanan 


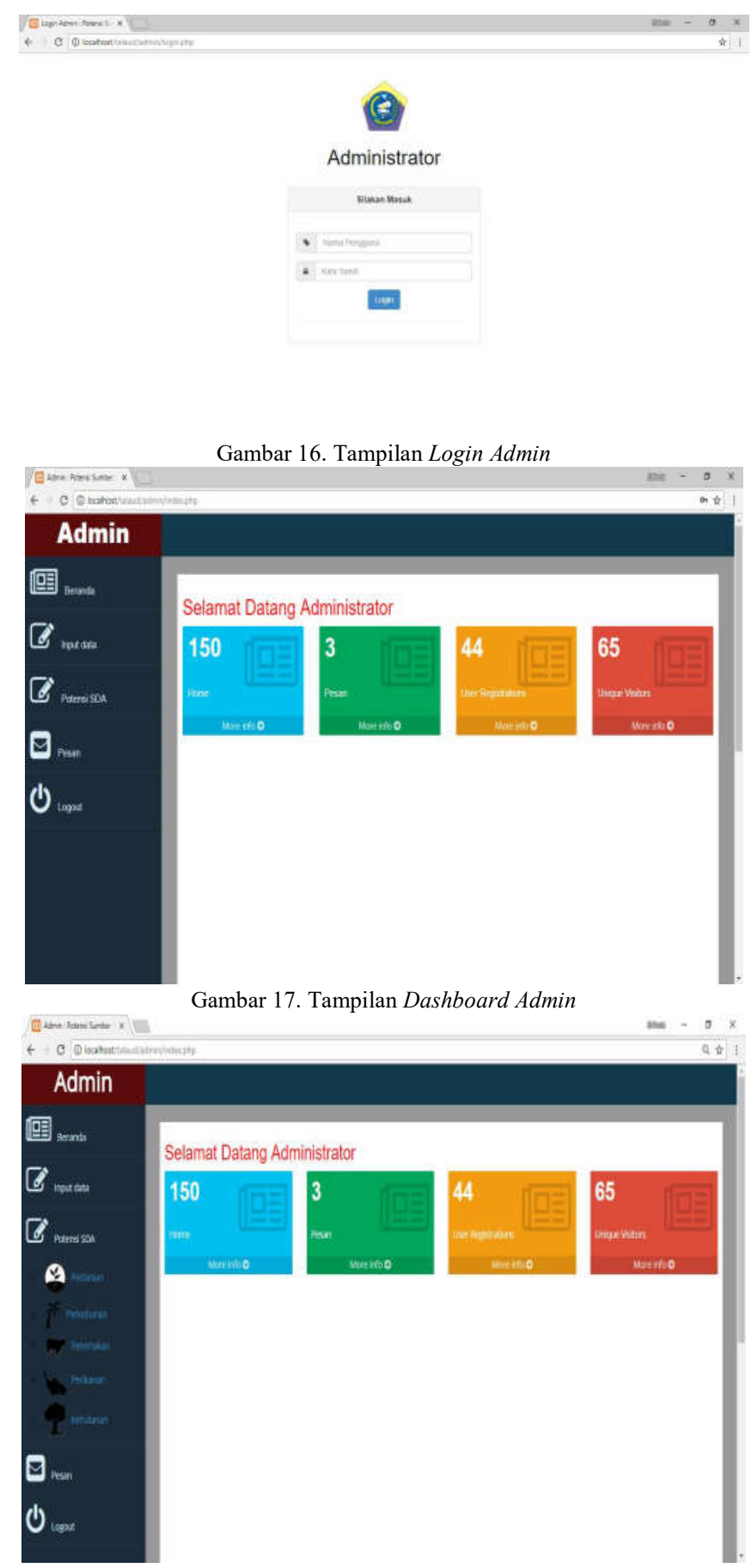

Gambar 18. Tampilan Menu Potensi SDA

\section{KESIMPULAN DAN SARAN}

Berdasarkan hasil dan pembahasan yang telah dilakukan, maka dapat diambil kesimpulan bawah Penulis berhasil merancang sistem informasi geografis berdasarkan data-data potensi sumber daya alam di Kabupaten Kepulauan Talaud, dan juga penulis berhasil menbangun web sistem informasi geografis Potensi Sumber daya alam. Adapun saran yang dapat diberikan dapat mengembangkan web potensi sumber daya alam di Kabupaten Talaud. Diharapkan dapat menambahkan fitur-fitur didalam sesuai kebutuhan kedepan dan juga bisa membuat aplikasi yang berbasis Android.
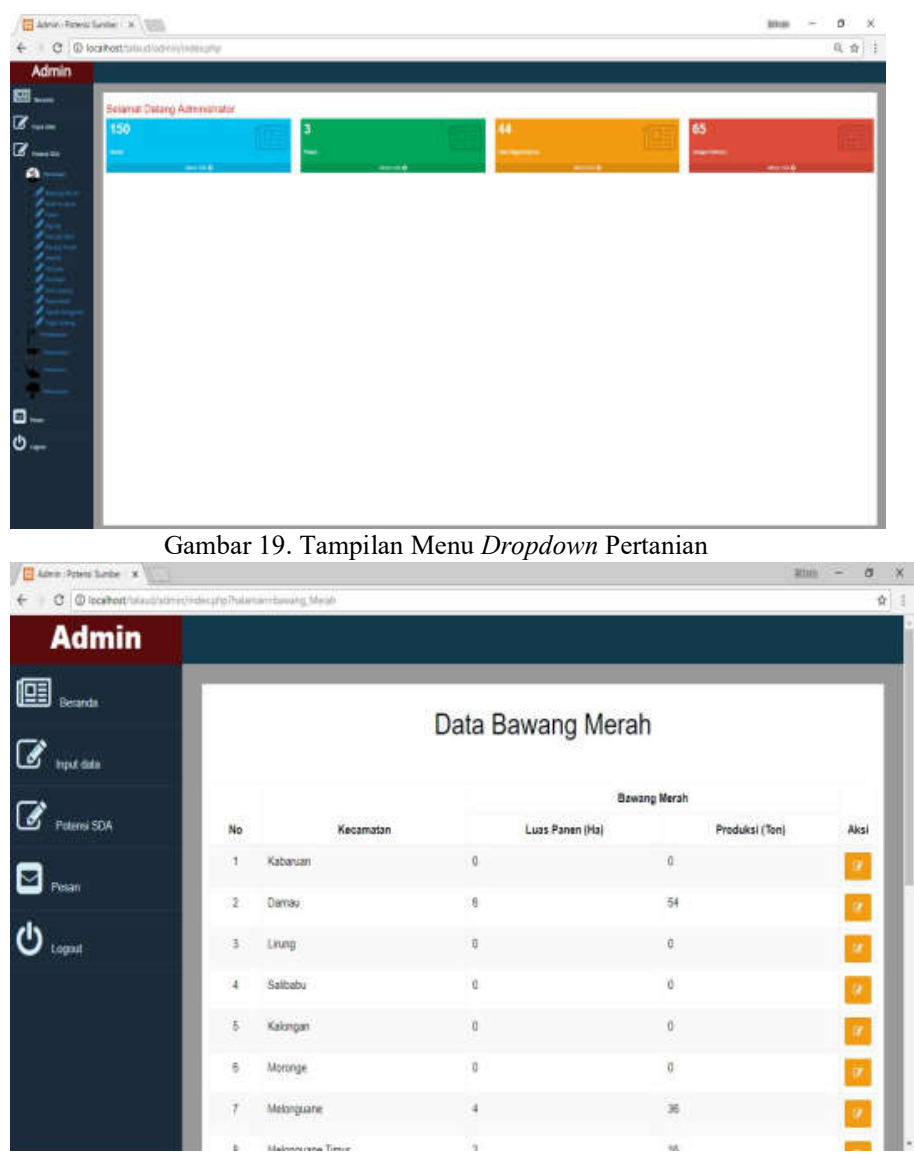

Gambar 20. Tampilan Menu Dropdown Bawang Merah

\section{V.KUTIPAN}

[1] A Suseno. (2012). "Penggunaan Quantum GIS Dalam Sistem Informasi Geografis", [online]. Tersedia di : http://ricky.staff.gunadarma.ac.id. Terjemahan Ricky, Agus, T., ST, SSI,MM. Bogor.

[2] A Tanjaya, "Perancangan Aplikasi katalog Produk Dan Pemesanan berbasi WEB Pada PT. Health Wealth International", Skripsi S1 Program Studi Sistem Informasi Sekolah Tinggi Manajemen Informasi Dan Komputer. Medan, 2015.

[3] Badan Pusat Statistik Kabupaten Kepulauan Talaud, "Kabupaten Kepulauan Talaud dalam Angka (2017)", (C) BPS Kabupaten Kepulauan Talaud/BPS-Statistics of Kepulauan Talaud, 2017.

[4] E Irwansyah, "Sistem Informasi Geografis Prinsip Dasar dan Pengembangan Aplikasi", Digibooks J1. Kaliurang KM.5 Gg. Sitisonya No. 95 Yogyakarta, 2013.

[5] I. W. E. Swastikayana, "Sistem Informasi Geografis Berbasis Web Untuk Pemetaan Pariwisata Kabupaten Gianyar", Skripsi Teknik Informatika Universitas Pembangunan Nasional"Veteran" Yogyakarta, 2011.

[6] Kumaat M, Steven R. Sentinuwo dan Agustinus Jacobus, "Rancang Bangun Sistem Informasi Geografis Jalur Angkutan Dalam Kota Di Kota Manado Berbasis Web", Vol 5, pp. 83, ISSN:2301-8402, (2016).

[7] Pressman, R, S, "Rekayasa Perangkat Lunak", Bab 2 (2.3.1 Model Air Terjun). Pendekatan Praktisi Edisi 7, Yogyakarta :Adi Nugroho, et. Al, 2012.

[8] T. D. Pamuji, "Sistem Informasi Geografi (SIG) Pemetaan Hutan Menurut Klasifikasi Sebagai Potensi Hutan Lidung”, Skripsi Program Studi Teknik Informatika Jenjang Progran Strata-1 Universitas Stikubank Semarang, 2013.

[9] Wibowo K. M, Kanedi, I. dan Jumadi, J, "Sistem Informasi Geografis (SIG) Menentukan Lokasi Pertambangan Batu Bara di Provinsi Bengkulu Berbasi WebSite”, Vol 11, pp. 2-4, (2015).

[10] Wijaya A dan Olvhie A, "Sistem Informasi Geografis Pemetaan Kantor Dinas Pemerintah Kota Palembang Menggunakan ArcGIS”, Seminar 
Nasional Teknologi Informasi dan Komunikasi Terapan 2014(SEMANTIK 2014), Semarang, 15 November 2014, ISBN:979-260276-3.

[11] Yayasan pelaGIS, "Modul Pelatihan Sistem Informasi Geografis Tingkat Lanjut ", Versi 2.0. Yayasan pelaGIS”, Jl. Elang, Lorong Enau, G. Ahmad Ali RT. 02 No. 18 Kampung Ateuk Pahlawan Kec. Baiturrahman, Banda Aceh 23241 Aceh, Indonresian, 2011.

[12] Z. A. Nur, "Sistem Pakar Untuk Diagnosa Kerusakan Handphon Dengan Metode Forward Chaining”, Skripsi Program Studi Pendidikan Teknik Informatika dan Komputer Universitas Negeri Semarang, 2015.

[13] Kevin G. Pramono, Steven R. Sentinuwo dan Yaulie D. Y. Rindengan. "Perancangan Model Sistem Informasi Sumber Daya Perikanan Wilayah Kepulauan", 2018.

Arief Aser Sasoeng lahir di Rainis pada tanggal 09 April 1995. Anak kedua dari pasangan Adriamal Sasoeng dan Suriati Tatambi.

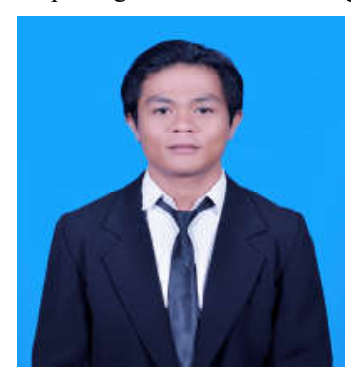

Dengan latar belakang pendidikan di Taman Kanak-Kanak Tunas Harapan Rainis (2000-2001). Kemudian melajutkan studi di sekolah dasar SDN Inpres Rainis (2001 2007). Kemudian melanjutkan studi ke Sekolah Menengah Pertama Negeri 1 Rainis (2007 - 2010) dan selanjutnya saya menempuh studi ke Sekolah Menengah Kejuruan Negeri 1 Talaud (2010 - 2013). Setelah itu, di tahun 2013 saya melanjutkan pendidikan ke salah satu perguruan tinggi yang berada di Manado yaitu Universitas Sam Ratulangi Manado, dengan mengambil Program Studi S-1 Teknik Informatika di Jurusan Elektro Fakultas Teknik. Pada Tahun 2017 bulan oktober, penulis membuat Skripsi demi memenuhi syarat Sarjana (S1) dengan penelitian berjudul Rancang Bangun Sistem Informasi Geografis Potensi Sumber Daya Alam Di Kabupaten Talaud Berbasis Web, yang dibimbing oleh dua dosen pembimbing yaitu Dr. Eng. Steven R. Sentinuwo, ST., MTI dan Yaulie D. Y. Rindengan, ST., MSc., MM. sehingga pada tanggal .. Juli 2018 penulis resmi lulus di Teknik Informatika Universitas Sam Ratulangi Manado menyandang gelar sarjana komputer dengan predikat sangat memuaskan.. 